\title{
Clinical characteristics of hospitalized mild/ moderate COVID-19 patients with a prolonged negative conversion time of SARS-CoV-2 nucleic acid detection
}

Ya Yang ${ }^{1}$, Xiaogang $\mathrm{Hu}^{2}$, Lirong Xiong ${ }^{1}$, Peishu Fu' ${ }^{1}$, Wei Feng ${ }^{1}$, Wei Li ${ }^{1}$, Liwen Zhang ${ }^{3^{*}}$ and Fengjun Sun ${ }^{1^{*}}$

\begin{abstract}
Background: The impact of COVID-19 has been devastating on a global scale. The negative conversion time (NCT) of SARS-CoV-2 RNA is closely related to clinical manifestation and disease progression in COVID-19 patients. Our study aimed to predict factors associated with prolonged NCT of SARS-CoV-2 RNA in mild/moderate COVID-19 patients.

Methods: The clinical features, laboratory data and treatment outcomes of COVID-19 patients were retrospectively analyzed. Then univariate and multivariate analysis were used to screen out risk factors of influencing prolonged NCT of SARS-COV-2 RNA.

Results: Thirty-two hospitalized mild/moderate COVID-19 patients were enrolled. The general clinical symptoms were cough (78.1\%), fever (75\%), diarrhea (68.8\%), expectoration (56.3\%), and nausea (37.5\%). More than $40 \%$ of the patients had decreased erythrocyte, hemoglobin and leucocyte and $93.8 \%$ patients were detected in abnormalities of chest CT. The median NCT of SARS-CoV-2 RNA was 19.5 days (IQR: 14.25-25). Univariate analysis found fever, nausea, diarrhea and abnormalities in chest CTs were positively associated with prolonged NCT of viral RNA ( $P<$ 0.05). The multivariate Cox proportional hazard model revealed that fever $[\mathrm{Exp}(\mathrm{B}), 0.284 ; 95 \% \mathrm{Cl}, 0.114-0.707 ; P<$ $0.05]$ and nausea [Exp (B), 0.257; 95\%Cl, 0.096-0.689; $P<0.05]$ were two significant independent factors.
\end{abstract}

Conclusions: Fever and nausea were two significant independent factors in prolonged NCT of viral RNA in mild/ moderate COVID-19 patients, which provided a useful references for disease progression and treatment of COVID-19.

Keywords: COVID-19, SARS-CoV-2, Clinical characteristics, Negative conversion time

\footnotetext{
* Correspondence: 763336760@qq.com; fengj_sun@163.com

${ }^{3}$ Department of Tuberculosis, Chongqing Public Health Medical Center, Chongqing 400036, China

'Department of Pharmacy, The First Affiliated Hospital of Army Medical University, Chongqing 400038, China

Full list of author information is available at the end of the article
}

(c) The Author(s). 2021 Open Access This article is licensed under a Creative Commons Attribution 4.0 International License, which permits use, sharing, adaptation, distribution and reproduction in any medium or format, as long as you give appropriate credit to the original author(s) and the source, provide a link to the Creative Commons licence, and indicate if changes were made. The images or other third party material in this article are included in the article's Creative Commons licence, unless indicated otherwise in a credit line to the material. If material is not included in the article's Creative Commons licence and your intended use is not permitted by statutory regulation or exceeds the permitted use, you will need to obtain permission directly from the copyright holder. To view a copy of this licence, visit http://creativecommons.org/licenses/by/4.0/ The Creative Commons Public Domain Dedication waiver (http://creativecommons.org/publicdomain/zero/1.0/) applies to the data made available in this article, unless otherwise stated in a credit line to the data. 


\section{Background}

In December 2019, novel pneumonia of unknown causes was reported in Wuhan, Hubei province in China. On February 11, 2020, the World Health Organization (WHO) officially named the disease as Coronavirus Disease 2019 (COVID-19), which caused by Severe Acute Respiratory Syndrome Coronavirus-2 (SARS-CoV-2). Following the initial outbreak, COVID-19 has become a global public health emergency of international concern [1]. There had been 23 million confirmed cases, and 800,000 confirmed deaths by 23 August 2020 spreaded across 216 countries and territories [2]. The number of COVID-19 patients has increased exponentially, causing devastation on a global scale [3].

According to the severity of the disease, COVID-19 patients were divided into asymptomatic, mild, moderate and severe cases. Mild/moderate COVID-19 patients has mild clinical symptoms and will develop into severe cases without timely treatment [4]. Therefor, it is very important to control the disease progression of mild/ moderate patients. The standard of cure is the relief of symptoms and two successive negative viral nucleic acid [4]. The negative conversion of SARS-CoV-2 RNA was essential in the discharge criteria during hospitalization $[5,6]$. The negative conversion time (NCT) of SARSCoV-2 RNA is closely related to clinical manifestation and disease progression in COVID-19 patients. Therefore, identification of factors associated with the NCT in COVID-19 could contribute to the disease progression and clinical outcomes. $\mathrm{Hu}$ et al. reported that older age and chest tightness were independently associated with delayed clearance of SARS-CoV-2 RNA in hospitalized patients [7]. The COVID-19 patients with digestive symptoms are more likely to test positive for viral RNA in a stool sample and have a longer delay before viral clearance than patients with only respiratory symptoms [8]. Several studies also focused on the effects of impaired immunity and blood system on NCT in COVID-19 patients. Wang et al. reported neutrophil to $\mathrm{CD} 4+$ lymphocyte ratio is a potential and useful biomarker for predicting the NCT in COVID-19 patients [9]. The integrated indicator of leucocytes, neutrophils and $\mathrm{CD} 3+\mathrm{CD} 4+$ lymphocytes showed a good performance in predicting the negative conversion [10]. Preliminary clinical treatment showed that some drugs, such as chloroquine, effectively potentiated virus clearance in COVID-19 patients [11]. However, there is limited data regarding the potential predictors of $\mathrm{NCT}$ in $\mathrm{mild} / \mathrm{mod}$ erate COVID-19 patients.

Therefore, this study analyzed clinical characteristics of NCT of SARS-CoV-2 RNA in mild/moderate COVID-19 patients, We hoped to find out the risk factors affecting NCT of SARS-CoV-2 RNA, which provided a useful references for disease progression and treatment of COVID-19.

\section{Methods \\ Subjects and data collection}

The clinical data and laboratory test results were analyzed retrospectively from 32 mild/moderate COVID-19 patients admitted to the Public Health Medical Center and Prevention of Chongqing from January 31 to February 28, 2020. All patients were identified to be nucleic acid positive for SARS-CoV-2 and were convalescent before hospital discharge.

Data was collected and recorded from each patient, which included demographic and clinical information (gender, age, smoking history, and comorbidities), clinical manifestations (fever, coughing, expectoration, anhelation, myalgia, nausea and vomiting, diarrhea, osphyalgia, etc.), and laboratory test results (standard blood counts, procalcitonin, C-reactive protein, blood biochemistry, coagulation function, and myocardial enzyme spectrum, etc). The normal range of laboratory examination is the standard of Reference Range Values for National Practice for Clinical Testing (4th Edition) published by People's Medical Publishing House [12]. Chest CT and therapeutic drug use were also documented. Then, the factors associated with NCT of SARS-CoV-2 RNA in upper respiratory specimens were analyzed.

\section{Therapeutic strategies}

Strategies of treatment for COVID-19 patients were shown in supplementary Figure 1. The primary treatment strategy is combined antiviral therapy, which mainly comprises interferon- $\alpha 2 b($ IFN- $\alpha 2 b)$ and lopinavir/ ritonavir (LPV/r) (group 1), IFN- $\alpha 2 \mathrm{~b}, \mathrm{LPV} / \mathrm{r}$ and ribavirin (group 2), IFN- $\alpha 2 \mathrm{~b}$ and ribavirin (group 3). When SARS-CoV-2 RNA was still detectable after 19 days of drug therapy, we discontinued current antiviral drugs and switched to combination of IFN- $\alpha 2 \mathrm{~b}$ and chloroquine phosphate which was defined as group 4(combination of IFN- $\alpha 2 b$ and Ribavirin, then combination of IFN- $\alpha 2 \mathrm{~b}$ and chloroquine phosphate) and group 5 (IFN$\alpha 2 b$ and LPV/r, then combination of IFN- $\alpha 2 b$ and chloroquine phosphate) until negative conversion of SARS-CoV-2 RNA.

\section{Definitions of basic concepts}

Throat swab specimens were collected from each patient every other day during hospitalization. RT-PCR assay was used to confirm COVID-19 patients through detecting the RNA of SARS-CoV-2 in throat swab samples. Patients with consecutive positive nucleic acid tests were confirmed as SARS-CoV-2 infection. The standard of negative conversion is two successive negative viral 
nucleic acid detection tests in $24 \mathrm{~h}$ minimum sampling intervals. The term convalescent patients refer to recovered afebrile patients without respiratory symptoms who had two successive (minimum $24 \mathrm{~h}$ sampling interval) negative results for SARS-CoV-2 RNA from oropharyngeal swabs by RT-PCR.

\section{Statistical analysis}

Normally distributed continuous variables are summarized as the mean mean (standard deviation, SD), otherwise, median (interquartile range, IQR) was used to describe. Categorical variables are expressed using numbers and percentages. Cox regression analysis was used to analyze the factors. First, univariate analysis was performed, and the indicators with statistical significance were analyzed for Kaplan-Meier survival analysis. The Log Rank method was used to compare the differences between groups. A Cox proportional hazard model was used for multivariate analysis. IBM SPSS Statistics 26 was used for statistical analysis and survival image rendering. $P<0.05$ was considered to indicate a statistically significant difference.

\section{Results}

The relationship between demographic and clinical information and NCT of SARS-CoV-2 RNA

Of these patients, males accounted for $43.8 \%$ (14) of confirmed cases, and $56.3 \%$ (18) were females. The median age of males and females was 34.00 (29.00, 47.00) years and $43.00(37.75,57.25)$ years respectively, suggesting that middle-aged people were more susceptible to infection than other age groups. A total of $12.5 \%$ of patients were smokers. More than a quarter of patients (34\%) had underlying diseases, including cardiovascular and cerebrovascular diseases (25\%), gastrointestinal disease $(15.6 \%)$, respiratory disease $(12.5 \%)$ and a neurological disorder (3.1\%). All patient data were analyzed using the Cox regression analysis for univariate analysis. However, we found that no demographic or clinical information had a significant positive association with NCT of viral RNA in patients $(P>0.05$, Table 1$)$.

\section{The relationship between clinical manifestation and NCT of SARS-CoV-2 RNA}

The median duration from disease onset to hospital admission was 3.5 (IQR: 2-6) days, with a median of 20 days from illness onset to hospital discharge (IQR: 15.25-26) and the median time from positive to negative conversion of SARS-CoV-2 RNA was 19.5 days (IQR: 14.25-25). The majority of the patients showed an initial symptom of fever $(75 \%)$, but a quarter of the patients were afebrile, alerting the need for the caution of atypical cases. In addition to fever, other clinical symptoms mainly included fatigue (78.1\%), expectoration (56.3\%), diarrhea (68.8\%), nausea (37.5\%), anhelation (34.4\%), and throat discomfort (34.4\%). Clinical manifestations of the study population are summarized in Table 1.

The Cox regression analysis was used for univariate analysis; we found that fever, nausea, and diarrhea were a significant positive association with NCT of viral RNA in patients $(P<0.05$, Table 1$)$. The Kaplan-Meier curves revealed that fever, nausea, and diarrhea had a significantly prolonged NCT of SARS-CoV-2 RNA compared with the normality's group $(P<0.05$; Fig. $1 \mathrm{a}, \mathrm{b}, \mathrm{c})$.

\section{The relationship between laboratory findings and NCT of SARS-CoV-2 RNA}

The laboratory inspection section showed that $43.8 \%$ of the patients developed leucopenia, and $28.1 \%$ of patients had lymphocytopenia. The hemoglobin, platelets, and albumin levels were lower in $53.1,37.5$, and $34.4 \%$ of patients, respectively. The levels of procalcitonin, Creactive protein, total bilirubin, direct bilirubin, creatinine, lactic dehydrogenase were increased in 9.4, 40.6, 40.6 , 46.9, 25, and $21.9 \%$ of patienst, respectively. All patient data were analyzed using the Cox regression analysis for univariate analysis. However, there were no significant findings with a positive association with NCT of viral RNA in patients $(P>0.05$, Supplementary Table 1).

\section{The relationship between radiological findings and NCT of SARS-CoV-2 RNA}

Ground-glass opacity (GGO) and high-density shadow were the typical radiological findings on chest $\mathrm{CT}$ scan in COVID-19 patients. Abnormalities in chest CT were detected in $93.8 \%$ of patients. A total of $87.5 \%$ of patients had ground-grass opacities over bilateral lungs, which was the most common pattern of CT changes and corresponded to pathological diffuse alveolar damage [13].

We analyzed the univariate analysis using the Cox regression and found that abnormalities in chest CT were a significant positive association with NCT of viral RNA in patients $(P<0.005$, Table 2$)$. The Kaplan Meier curves revealed that abnormalities in chest $\mathrm{CT}$ had a significantly prolonged NCT of SARS-CoV-2 RNA compared with normality's group $(P<0.05$; Fig. $1 d)$.

\section{Taking antiviral medications during hospitalization}

The treatment strategy and the NCT were shown in supplementary Figure 1. The median time from positive to negative conversion of SARS-CoV-2 RNA was 19.5 days (IQR: 14.25-25). The univariate analysis using the Cox regression and found that combined treatment of IFN$\alpha 2 \mathrm{~b}$ and LPV/r (group 1) had a significantly shorten NCT of SARS-CoV-2 RNA ([Exp (B),12.522; 95\% CI, 3.389 46.263; $P<0.05]$ ), which is consistent with other 
Table 1 Univariate analysis of demographic and clinical information on NCT of SARS-CoV-2 RNA in 32 COVID-19 patients

\begin{tabular}{|c|c|c|c|c|c|}
\hline \multirow[t]{2}{*}{ Factors } & \multirow{2}{*}{$\begin{array}{l}\text { Count } \\
\text { n (\%) }\end{array}$} & \multirow{2}{*}{$\begin{array}{l}p \\
\text { value }\end{array}$} & \multirow[t]{2}{*}{$\operatorname{Exp}(B)$} & \multicolumn{2}{|c|}{ 95.0\% Cl for $\operatorname{Exp(B)}$} \\
\hline & & & & lower limit & detection limits \\
\hline \multicolumn{6}{|l|}{ Demographic and clinical information } \\
\hline \multicolumn{6}{|l|}{ Age breakdown } \\
\hline$<45$ & $21(65.6)$ & 0.636 & 1.190 & 0.579 & 2.446 \\
\hline$>45$ & $11(34.4)$ & & & & \\
\hline \multicolumn{6}{|l|}{ Sex } \\
\hline Male & $14(43.8)$ & 0.689 & 1.325 & 0.398 & 4.411 \\
\hline Female & $18(56.3)$ & & & & \\
\hline Smoking & $4(12.5)$ & 0.988 & 0.992 & 0.343 & 2.868 \\
\hline \multicolumn{6}{|l|}{ Underlying diseases } \\
\hline Hypertension & $3(9.4)$ & 0.710 & 1.257 & 0.376 & 4.197 \\
\hline Diabetes & $1(3.1)$ & 0.110 & 5.750 & 0.671 & 49.244 \\
\hline Coronary heart disease & $1(3.1)$ & 0.252 & 3.373 & 0.421 & 26.993 \\
\hline Viral hepatitis type B & $2(6.3)$ & 0.399 & 0.536 & 0.126 & 2.282 \\
\hline Hyperlipemia & $2(6.3)$ & 0.199 & 0.550 & 0.221 & 1.370 \\
\hline Cerebral hemorrhage & $1(3.1)$ & 0.593 & 0.578 & 0.078 & 4.305 \\
\hline Chronic bronchitis & $1(3.1)$ & 0.110 & 5.750 & 0.671 & 49.244 \\
\hline Depression & $1(3.1)$ & 0.075 & 7.340 & 0.820 & 65.691 \\
\hline Pneumonia & $1(3.1)$ & 0.258 & 0.312 & 0.042 & 2.342 \\
\hline \multicolumn{6}{|l|}{ Clinical manifestation } \\
\hline The duration from disease onset to hospital & $32(100)$ & 0.345 & 1.057 & 0.940 & 1.190 \\
\hline Fever & $24(75.0)$ & $0.050^{*}$ & 0.431 & 0.186 & 1.000 \\
\hline Cough & $25(78.1)$ & 0.564 & 0.779 & 0.334 & 1.818 \\
\hline Expectoration & $18(56.3)$ & 0.335 & 0.707 & 0.349 & 1.431 \\
\hline Anhelation & $11(34.4)$ & 0.714 & 0.871 & 0.416 & 1.822 \\
\hline Throat discomfort & $11(34.4)$ & 0.669 & 0.852 & 0.409 & 1.775 \\
\hline Headache and dizziness & $7(21.9)$ & 0.323 & 0.650 & 0.277 & 1.526 \\
\hline Myodynia & $7(21.9)$ & 0.123 & 0.491 & 0.199 & 1.213 \\
\hline Osphyalgia & $2(6.3)$ & 0.341 & 0.495 & 0.117 & 2.103 \\
\hline Diarrhea & $22(68.8)$ & $0.007^{*}$ & 0.318 & 0.138 & 0.733 \\
\hline Ventosity & $2(6.3)$ & 0.524 & 0.622 & 0.145 & 2.677 \\
\hline Nausea & $12(37.5)$ & $0.002^{*}$ & 0.262 & 0.112 & 0.613 \\
\hline Vomiting & $3(9.4)$ & 0.314 & 2.161 & 0.482 & 9.686 \\
\hline Muscular stiffness & $5(15.6)$ & 0.235 & 0.559 & 0.214 & 1.460 \\
\hline Chills & $2(6.3)$ & 0.126 & 3.288 & 0.716 & 15.105 \\
\hline Fatigue & $9(28.1)$ & 0.509 & 0.768 & 0.350 & 1.683 \\
\hline Snot & $3(9.4)$ & 0.123 & 0.387 & 0.113 & 1.329 \\
\hline Insomnia & $5(15.6)$ & 0.444 & 0.678 & 0.250 & 1.836 \\
\hline Chest tightness & $5(15.6)$ & 0.978 & 1.014 & 0.385 & 2.670 \\
\hline
\end{tabular}

Data are shown as $\mathrm{n}(\%)$ or IQR unless specified otherwise

The Log Rank method was used to compare the differences between groups, $p<0.05$ was considered to indicate a statistically significant difference (indicated by *)

clinical treatments [14]. But combination of IFN- $\alpha 2 b$ and chloroquine phosphate (group 5) had a significantly prolonged NCT of SARS-CoV-2 RNA ([Exp (B),0.388;
95\% CI, $0.1820 .827 ; P<0.05]$ ), which group had a high percentage of gastrointestinal symptoms such as nausea and diarrhea (Data not shown) that may be risk factors 


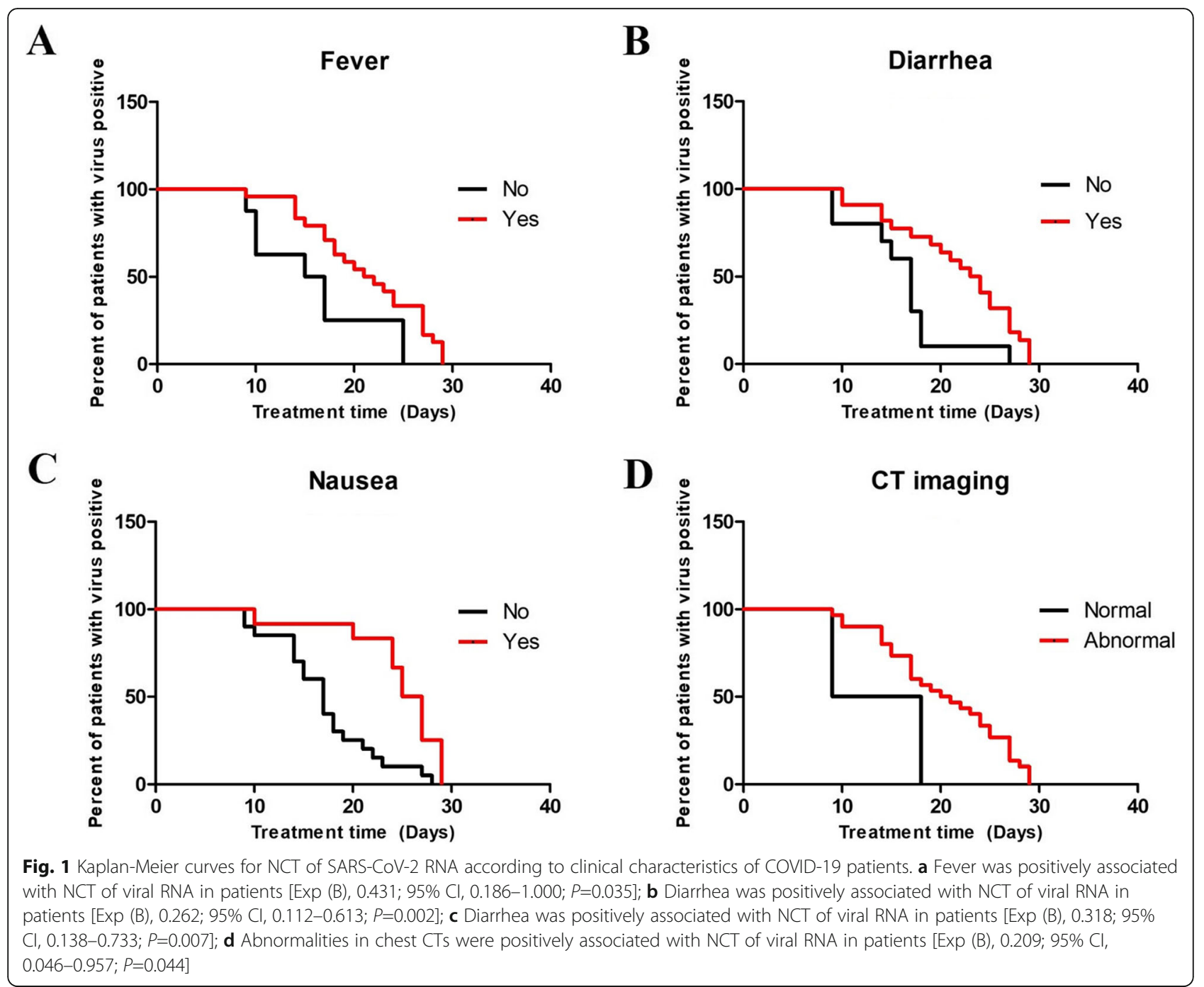

Table 2 The relationship between radiological findings ${ }^{a}$ and NCT of SARS-CoV-2 RNA in 32 patients with COVID-19

\begin{tabular}{|c|c|c|c|c|c|}
\hline \multirow[t]{2}{*}{ Factors } & \multirow{2}{*}{$\begin{array}{l}\text { Count } \\
\text { n (\%) }\end{array}$} & \multirow[t]{2}{*}{$p$ value } & \multirow[t]{2}{*}{$\operatorname{Exp}(B)$} & \multicolumn{2}{|c|}{$95.0 \% \mathrm{Cl}$ for $\operatorname{Exp}(\mathrm{B})$} \\
\hline & & & & lower limit & detection limits \\
\hline Total & $32(100)$ & & & & \\
\hline Abnormal & $30(93.8)$ & $0.044^{*}$ & 0.209 & 0.046 & 0.957 \\
\hline \multicolumn{6}{|l|}{ Involved lung field } \\
\hline Unilateral & $8(25)$ & 0.202 & 0.570 & 0.241 & 1.350 \\
\hline Bilateral & $22(68.8)$ & 0.503 & 1.314 & 0.591 & 2.920 \\
\hline \multicolumn{6}{|l|}{ Radiological characteristics } \\
\hline Ground-grass opacities & $28(87.5)$ & 0.940 & 0.960 & 0.331 & 2782 \\
\hline High-density shadow & $17(53.1)$ & 0.083 & 0.536 & 0.265 & 1.086 \\
\hline
\end{tabular}

Data are shown as $\mathrm{n}(\%)$ unless specified otherwise

The Log Rank method was used to compare the differences between groups, $p<0.05$ was considered to indicate a statistically significant difference (indicated by *) 
for NCT extension. Treatment of groups 2, 3 and 4 didn't shorten or prolong the NCT $(P>0.05)$.

\section{Multivariate analysis of risk factors of influencing prolonged NCT of SARS-CoV-2 RNA}

We had summarized the results of the univariate analysis that fever, nausea, diarrhea, and abnormalities in chest CT had a significantly prolonged NCT of SARS-CoV-2 RNA. To analyze factors on NCT of SARS-CoV-2 RNA systematically, the multivariate Cox's proportional hazard model was used to analyze the multivariate analyses. We revealed that fever [Exp (B), 0.284; 95\% CI, 0.114-0.707; $P<0.005$ ] and nausea [Exp (B), 0.257; 95\%CI, 0.096-0.689; $P<0.005$ ] were independent risk factors of prolonged NCT of SARSCoV-2 RNA in patients with COVID-19 (Table 3).

\section{Discussion}

COVID-19 is a global pandemic that has rapidly spread worldwide since reported in December 2019. A negative nucleic acid test of SARS-CoV-2 is the standard for a cure of COVID-19. To investigate the timeline of RNA negative conversion of COVID-19 patients, this study retrospectively analyzed clinical characteristics in a cohort of mild/moderate hospitalized patients in Chongqing, China. We found that fever, nausea, diarrhea, and abnormalities in chest $\mathrm{CT}$ were correlated to a prolonged NCT of SARS-CoV-2 RNA. More importantly, fever and nausea were the independent factors predicting NCT of mild/moderate COVID-19 patients.

Fever, a respiratory manifestation, is the most commonly reported symptom in patients infected with SARSCoV-2 $[15,16]$. Accordingly, fever may be a clinical sign of poor prognosis in patients and response to the release of inflammatory mediators such as cytokines and chemokines $[17,18]$. These inflammatory mediators cause tissue damage and organ dysfunction by stimulating toxic oxygen derivatives suggesting that the NCT of SARS-CoV-2 RNA may be prolonged in fever patients $[19,20]$.

Chest CT has a high sensitivity to detect lung abnormalities, which is quite helpful in the early diagnosis of the disease. The "Diagnosis and Treatment Scheme for

Table $\mathbf{3}$ Independent factors of NCT of SARS-CoV-2 RNA by the multivariate Cox's proportional hazard model

\begin{tabular}{|c|c|c|c|c|}
\hline \multirow[t]{2}{*}{ Factors } & \multirow{2}{*}{$\begin{array}{l}p \\
\text { value }\end{array}$} & \multirow[t]{2}{*}{$\operatorname{Exp}(B)$} & \multicolumn{2}{|c|}{$95.0 \% \mathrm{Cl}$ for $\operatorname{Exp}(\mathrm{B})$} \\
\hline & & & lower limit & detection limits \\
\hline Fever & $0.007^{*}$ & 0.284 & 0.114 & 0.707 \\
\hline Nausea & $0.007^{*}$ & 0.257 & 0.096 & 0.689 \\
\hline Diarrhea & 0.376 & 0.648 & 0.248 & 1.692 \\
\hline $\mathrm{CT}$ imaging & 0.150 & 0.299 & 0.058 & 1.550 \\
\hline
\end{tabular}

A Cox proportional hazard model was used for multivariate analysis, $p<0.05$ was considered to indicate a statistically significant difference (indicated by *)
Coronavirus Disease (Trial Version 7)" recommended that a CT examination serves as the diagnostic basis for COVID-19. For chest imaging in patients with COVID19 , the early manifestation was multiple plaque shadows and interstitial changes. The later development was multiple ground glass shadows and infiltration shadows in both lungs. In severe cases, lung consolidation can occur, presenting as "white lung," which may be related to the immunopathology. Most studies have suggested that a dysregulated/exuberant innate responses are the primary cause of coronavirus-mediated pathology [21]. Many cytokines or chemokines are involved in the immune storm after the infection of coronavirus, which eventually leads to lung injury and acute respiratory distress syndrome [22]. The improvement of chest CT was after that of body temperature. It preceded the negative conversion of nucleic acid tests, suggesting that abnormalities in chest CT could indirectly reflect the persistence of SARS-CoV-2 RNA in patients with COVID-19. Our study found that abnormalities in chest CT could prolong the NCT of patients with COVID-19. Therefore, the improvement of chest CT as soon as possible has an essential effect on shortening NCT in patients with COVID-19 and promoting patients to be discharged more rapidly.

Although COVID-19 most commonly presents with respiratory symptoms, such as cough and shortness of breath $[15,23,24]$, there is evidence that the illness can also present with nonrespiratory symptoms, most notably digestive symptoms such as diarrhea, diminished appetite, nausea, and vomiting [25-27]. Diarrhea appeared to be the most common GI complaint [28], followed by nausea and vomiting [23]. SARS-CoV-2 RNA was detected in stool samples from COVID-19 patients for the first reported in the United States [29]. Viral RNA was still positive in gastrointestinal specimens even after virus RNA levels could not be detected in respiratory samples [28], implying direct infectivity of the virus on the intestinal tract. Current research shows that the primary target organ of COVID-19 is the lung, but clinical evidence suggests that the gastrointestinal tract may be another viral target organ.

The SARS-CoV-2 receptor angiotensin-converting enzyme 2 (ACE2) has been found in both upper and lower gastrointestinal tract where its expression level was nearly 100 times higher than that of respiratory organs $[30,31]$. Patients with symptoms of the digestive system have more viruses in their gut [8], and maybe more likely to cause direct damage to the intestinal mucosa. Our research found that digestive symptoms, including nausea and diarrhea, are the factors of NCT of COVID19 patients, suggesting that patients with gastrointestinal symptoms should seek medical care to avoid delayed diagnosis and prolong treatment time. 
There are several limitations to our study. First, the sample size of this study is not large enough. Second, we have not conducted randomized controlled trials, so we cannot determine the therapeutic effect of chloroquine on COVID-19 and its impact on shortening the time of negative viral conversion.

\section{Conclusion}

In conclusion, our study suggests that fever, nausea, diarrhea, abnormalities in chest $\mathrm{CT}$ and are risk factors for prolonged NCT of SARS-COV-2 RNA in mild/moderate COVID-19 patients. More importantly, fever and nausea are the independent factors in predicting prolonged NCT of SARS-CoV-2 RNA. Meanwhile, we should pay attention to gastrointestinal symptoms and provide timely treatment. This study provide a useful references for disease progression and treatment of COVID-19.

\section{Supplementary Information}

The online version contains supplementary material available at https://doi. org/10.1186/s12879-021-05851-z.

Additional file 1: Supplementary Figure 1. Schematic illustration of the treatment strategy and days medication use during hospitalization in 32 COVID-19 patients. Group 1: patient number 1-11. Combined treatment of IFN-a2b and LPV/r. Group 2: patient number 12-17. Combined treatment of IFN-a2b, LPV/r and ribavirin, Group 3: patient number 18-19. Combined treatment of IFN- $a 2 b$ and ribavirin. Group 4: patient number 20-21. Combined treatment of IFN-a2b and ribavirin for 19 days and switched to combination of IFN- $a 2 b$ and chloroquine phosphate. Group 5: patient number 22-32. Combined treatment of IFN-a2b and LPV/r for 19 days and switched to combination of IFN-a2b and chloroquine phosphate.

Additional file 2: Supplementary Table 1. The relationship between laboratory findings and NCT of SARS-CoV-2 RNA in 32 patients with COVID-19

\section{Abbreviations}

COVID-19: Coronavirus disease 2019; SARS-CoV-2: Severe Acute Respiratory Syndrome Coronavirus-2; NCT: Negative conversion time; RT-PCR: Reverse Transcription-polymerase Chain Reaction; CT: Computerized tomography; IFN-a2b: Interferon-a2b; IQR: Interquartile range; GGO: Ground-glass opacities

\section{Acknowledgements}

We would like to thank all physicians that participated in this study for patient enrollment and follow-up.

\section{Authors' contributions}

$F S, L Z, Y Y$ and $X H$ conceived and designed the project and had roles in the data analysis, data interpretation, literature search, and writing of the manuscript. LX, PF, WF and WL had roles in data collection, data interpretation, iterature search, and writing of the manuscript. LZ had roles in clinical management and data collection, and had full access to all of the data in the study and take responsibility for the integrity of the data. The authors read and approved the final manuscript.

\section{Funding}

The authors received no specific funding for this work.

\section{Availability of data and materials}

The datasets used and/or analyzed during the current study are available from the corresponding author on reasonable request.

\section{Ethics approval and consent to participate}

This study was conducted following the Declaration of Helsinki. It was approved by the Ethics Commission of Chongqing Public Health Medical Center (ethics approval registration number:2020-043-01-KY) and written informed consent was waived in consideration of the emergency of infectious disease.

\section{Consent for publication}

Not applicable.

\section{Competing interests}

The authors declare that they have no competing interests.

\section{Author details}

${ }^{1}$ Department of Pharmacy, The First Affiliated Hospital of Army Medical University, Chongqing 400038, China. '2Department of Pharmacy, Chongqing University Cancer Hospital, Chongqing 400030, China. ${ }^{3}$ Department of Tuberculosis, Chongqing Public Health Medical Center, Chongqing 400036, China.

Received: 28 August 2020 Accepted: 28 January 2021

Published online: 03 February 2021

\section{References}

1. Zhu N, Zhang D, Wang W, Li X, Yang B, Song J, Zhao X, Huang B, Shi W, Lu R, et al. A Novel Coronavirus from Patients with Pneumonia in China, 2019. New Engl J Med. 2020;382(8):727-33.

2. Chen W, Gao N, Wang JL, Tian YP, Chen ZT, An J. Vimentin is required for dengue virus serotype 2 infection but microtubules are not necessary for this process. Arch Virol. 2008;153(9):1777-81.

3. Reuben RC, Danladi MMA, Pennap GR. Is the COVID-19 pandemic masking the deadlier Lassa fever epidemic in Nigeria? J Clin Virol. 2020;128:104434.

4. Chen Z, Tian Y, Liu L, An J. Production of a monoclonal antibody against non-structural protein 3 of dengue-2 virus by intrasplenic injection. Hybridoma. 2008;27(6):467-71.

5. Chan JF, Yip CC, To KK, Tang TH, Wong SC, Leung KH, Fung AY, Ng AC, Zou Z, Tsoi HW, et al. Improved Molecular Diagnosis of COVID-19 by the Novel, Highly Sensitive and Specific COVID-19-RdRp/Hel Real-Time Reverse Transcription-PCR Assay Validated In Vitro and with Clinical Specimens. J Clin Microbiol. 2020;58(5):e00310-20.

6. Chu DKW, Pan Y, Cheng SMS, Hui KPY, Krishnan P, Liu Y, Ng DYM, Wan CKC, Yang P, Wang Q, et al. Molecular Diagnosis of a Novel Coronavirus (2019nCoV) Causing an Outbreak of Pneumonia. Clin Chem. 2020;66(4):549-55.

7. Hu X, Xing Y, Jia J, Ni W, Liang J, Zhao D, Song X, Gao R, Jiang F. Factors associated with negative conversion of viral RNA in patients hospitalized with COVID-19. Sci Total Enviro. 2020;728:138812.

8. Han C, Duan C, Zhang S, Spiegel B, Shi H, Wang W, Zhang L, Lin R, Liu J, Ding Z, et al. Digestive Symptoms in COVID-19 Patients With Mild Disease Severity: Clinical Presentation, Stool Viral RNA Testing, and Outcomes. Am J Gastroenterol. 2020;115(6):916-23.

9. Wang $H Z$, Zhang $Y X, M o ~ P Z$, Liu J, Wang HL, Wang F, Zhao Q. Neutrophil to CD4+lymphocyte ratio as a potential biomarker in predicting virus negative conversion time in COVID-19. Int Immunopharmacol. 2020;85:106683.

10. Mo PZ, Deng LP, Liu XP, Gao SC, Liang K, Luo MQ, Chen TL, Song SH, Ma $Z Y$, Chen XP, et al. Risk factors for delayed negative conversion of SARSCoV-2 in patients with COVID-19 pneumonia: a retrospective cohort study. Epidemiol Infect. 2020;148:e293.

11. Gao J, Tian Z, Yang X. Breakthrough: Chloroquine phosphate has shown apparent efficacy in treatment of COVID-19 associated pneumonia in clinical studies. Biosci Trends. 2020;14(1):72-3.

12. Liu L, Tian Y, Gao N, Chen Z, Zhang H, An J. Application of antibodies against nonstructural protein $2 \mathrm{~B}$ of dengue serotype 2 virus induced by DNA immunisation or recombinant protein NS $2 B$ immunisation in BALB/C mice. J Virol Methods. 2010;163(1):10-6.

13. Chong S, Kim TS, Cho EY. Herpes simplex virus pneumonia: high-resolution CT findings. Brit J Radiol. 2010;83(991):585-9.

14. Zuo Y, Liu YL, Zhong Q, Zhang K, Xu YH, Wang ZX. Lopinavir/ritonavir and interferon combination therapy may help shorten the duration of viral shedding in patients with COVID-19: A retrospective study in two designated hospitals in Anhui, China. J Med Virol. 2020;92(11):2666-74. 
15. Huang C, Wang Y, Li X, Ren L, Zhao J, Hu Y, Zhang L, Fan G, Xu J, Gu X, et al. Clinical features of patients infected with 2019 novel coronavirus in Wuhan, China. Lancet. 2020;395(10223):497-506.

16. Wang D, Hu B, Hu C, Zhu F, Liu X, Zhang J, Wang B, Xiang H, Cheng Z, Xiong Y, et al. Clinical Characteristics of 138 Hospitalized Patients With 2019 Novel Coronavirus-Infected Pneumonia in Wuhan, China. JAMA. 2020;323: 1061-9.

17. Chen H, Lin C, Fan Z, Yu W, Cao M, Ke C, Jiao X. Serum cytokines and clinical features in patients with fever and thrombocytopenia syndrome. Clin Chim Acta. 2019;494:22-30.

18. Liu Y, Freed DC, Li L, Tang A, Li F, Murray EM, Adler SP, McVoy MA, Rupp RE, Barrett D, et al. A Replication-Defective Human Cytomegalovirus Vaccine Elicits Humoral Immune Responses Analogous to Those with Natural Infection. J Virol. 2019;93(23):e00747-19.

19. Korish AA, Arafa MM. Propolis derivatives inhibit the systemic inflammatory response and protect hepatic and neuronal cells in acute septic shock. Braz J Infect Dis. 2011;15(4):332-8.

20. Mittal M, Siddiqui MR, Tran K, Reddy SP, Malik AB. Reactive oxygen species in inflammation and tissue injury. Antioxid Redox Signal. 2014;20(7):1126-67.

21. Channappanavar R, Zhao J, Perlman S. T cell-mediated immune response to respiratory coronaviruses. Immunol Res. 2014;59(1-3):118-28.

22. Huang KJ, Su IJ, Theron M, Wu YC, Lai SK, Liu CC, Lei HY. An interferongamma-related cytokine storm in SARS patients. J Med Virol. 2005;75(2):18594.

23. Chen N, Zhou M, Dong X, Qu J, Gong F, Han Y, Qiu Y, Wang J, Liu Y, Wei Y, et al. Epidemiological and clinical characteristics of 99 cases of 2019 novel coronavirus pneumonia in Wuhan, China: a descriptive study. Lancet. 2020; 395(10223):507-13.

24. Xu XW, Wu XX, Jiang XG, Xu KJ, Ying $L$, Ma CL, Li SB, Wang HY, Zhang $S$, Gao HN, et al. Clinical findings in a group of patients infected with the 2019 novel coronavirus (SARS-Cov-2) outside of Wuhan, China: retrospective case series. BMJ. 2020;368:m606.

25. Chan JF, Yuan S, Kok KH, To KK, Chu H, Yang J, Xing F, Liu J, Yip CC, Poon RW, et al. A familial cluster of pneumonia associated with the 2019 novel coronavirus indicating person-to-person transmission: a study of a family cluster. Lancet. 2020;395(10223):514-23.

26. Pan L, Mu M, Yang P, Sun Y, Wang R, Yan J, Li P, Hu B, Wang J, Hu C, et al. Clinical Characteristics of COVID-19 Patients With Digestive Symptoms in Hubei, China: A Descriptive, Cross-Sectional, Multicenter Study. Am J Gastroenterol. 2020;115(5):766-73.

27. Guan WJ, Ni ZY, Hu Y, Liang WH, Ou CQ, He JX, Liu L, Shan H, Lei CL, Hui DSC, et al. Clinical Characteristics of Coronavirus Disease 2019 in China. New Engl J Med. 2020;382(18):1708-20.

28. Xiao F, Tang M, Zheng X, Liu Y, Li X, Shan H. Evidence for Gastrointestinal Infection of SARS-CoV-2. Gastroenterology. 2020;158(6):1831-1833 e1833.

29. Holshue ML, DeBolt C, Lindquist S, Lofy KH, Wiesman J, Bruce H, Spitters C Ericson K, Wilkerson S, Tural A, et al. First Case of 2019 Novel Coronavirus in the United States. New Engl J Med. 2020:382(10):929-36.

30. Kovacevic T, Miljkovic B, Mikov M, Stojisavljevic Satara S, Dragic S, Momcicevic D, Kovacevic P. The Effect of Hypoalbuminemia on the Therapeutic Concentration and Dosage of Vancomycin in Critically III Septic Patients in Low-Resource Countries. Dose Response. 2019;17(2): 1559325819850419.

31. Lamers MM, Beumer J, van der Vaart J, Knoops K, Puschhof J, Breugem TI, Ravelli RBG, Paul van Schayck J, Mykytyn AZ, Duimel HQ, et al. SARS-CoV-2 productively infects human gut enterocytes. Science. 2020;369(6499):50-4.

\section{Publisher's Note}

Springer Nature remains neutral with regard to jurisdictional claims in published maps and institutional affiliations.

Ready to submit your research? Choose BMC and benefit from:

- fast, convenient online submission

- thorough peer review by experienced researchers in your field

- rapid publication on acceptance

- support for research data, including large and complex data types

- gold Open Access which fosters wider collaboration and increased citations

- maximum visibility for your research: over $100 \mathrm{M}$ website views per year

At $\mathrm{BMC}$, research is always in progress.

Learn more biomedcentral.com/submissions 